\title{
Functional and Structural Changes in the Small Intestine in Children with Hookworm Infection
}

\author{
D. K. GUHA, ${ }^{\star}$ B. N. S. WALIA, B. N. TANDON, and O. P. GHAI \\ From the Departments of Pediatrics and Medicine, All India Institute of Medical Sciences, \\ New Delhi, India
}

Hookworm infection is prevalent in tropical countries, and much attention has been paid to the various aspects of anaemia associated with it (World Health Organization, 1959). Gastro-intestinal disturbances, such as anorexia, diarrhoea, abdominal pain, and flatulence, are also often noted in patients with hookworm infection. Advances in methods for studying the functional and structural status of the small bowel have enabled study of the pathogenesis of these clinical manifestations. Rotter (1931) first suggested that intestinal absorption might be impaired in this condition, and recently several authors have reported structural abnormalities in the small intestine in adults with hookworm infection (Sheehy et al., 1962; Salem and Truelove, 1964; Chaudhuri and Saha, 1964; Tandon et al., 1966). The present communication reports our observations on 14 children with hookworm infection.

\section{Material and Methods}

Studies were made of 14 children between the ages of 4 and 12 years, who were suffering from hookworm infection in association with microcytic hypochromic anaemia; in addition 14 children with no evidence of anaemia, gastro-intestinal or renal disease, served as controls. The following investigations were carried out.

Stools were examined by the saline-iodine preparation and/or the concentration method; haemoglobin was estimated by the cyanmethaemoglobin method (Williams and Zak, 1957); and haematocrit, reticulocyte count, haemogram, and bone-marrow examination by standard methods (Dacie, 1956); bone-marrow was stained for haemosiderin by Douglas and Dacie's method (1953); serum iron was estimated by the method of Ramsay (1958), unbound iron-binding capacity by the method of Ressler and Zak (1958), and serum protein by the biuret method of King and Wooton (1956). Occult

\footnotetext{
Received June 12, 1967.

* Present address: Victoria Zanana Hospital, Jama Masjid, Delhi-6, India.
}

blood in stool was determined by the benzidine test. A fat balance study was carried out over a 6-day period on a diet containing $50 \mathrm{~g}$. fat (van de Kamer, ten Bokkel Huinink, and Weyers, 1949). A 5 g. D-xylose absorption test was done (Butterworth et al., 1959). The 5-hour urinary $\mathrm{D}$-xylose excretion was estimated by the method of Roe and Rice (1948). Jejunal biopsy (Rubin's multipurpose biopsy tube) was performed in 12 children, and the histopathological changes were graded without the knowledge of the clinical data.

After completion of the above investigations, patients were treated with a single dose of $5 \mathrm{~g}$. bephenium. Iron dextran complex was administered intramuscularly in all patients with evidence of iron deficiency. The total dose of imferon was calculated according to the formula of Smith (1960). 8 to 24 weeks after initiation of therapy, 12 children were investigated a second time.

\section{Results}

The haematological and other data are summarized in the Table. The mean $D$-xylose and faecal fat excretion in controls were $1.481 \mathrm{~g} . / 5 \mathrm{hr}$. urine $/ 5 \mathrm{~g}$. dose, and $3 \cdot 1 \mathrm{~g}$./day, respectively.

The 5-hour D-xylose excretion was found to be less than $1 \mathrm{~g}$. in 7 patients (range $510-877 \mathrm{mg}$.). The daily fat excretion was noted to be increased in 8 patients. Most patients had a mild steatorrhoea (maximum excretion 12 g./day). Histological abnormalities were detected in the small intestine in 5 of the 12 jejunal biopsies. Grade I changes in 3 children consisted of some blunting and fusion of villi and increased cellular infiltration in the lamina propria. The villous crypt ratio was more or less normal. The villous epithelial cells were properly oriented and showed no abnormalities. Grade II abnormality was observed in 2 cases: these changes were characterized by moderate reduction in the villous: crypt ratio, to $1: 1$ or $2: 1$. The villi showed varying degrees of fusion and blunting (Fig. 1). A moderate amount of cellular infiltration was detected in the lamina propria. Goblet cells were increased, but the epithelial cells 
TABLE

Summary of Cases

\begin{tabular}{|c|c|c|c|c|c|c|c|c|c|c|c|c|c|c|c|}
\hline & $\begin{array}{l}\text { Case } \\
\text { and }\end{array}$ & $\begin{array}{l}\text { No., Sex } \\
\text { Age (yr.) }\end{array}$ & & $\begin{array}{c}\text { Height } \\
\text { (cm.) }\end{array}$ & $\begin{array}{c}\text { Weight } \\
(\mathrm{kg}) .\end{array}$ & $\begin{array}{c}\mathrm{Hb} \\
(\mathrm{g} . / \\
100 \mathrm{ml} .)\end{array}$ & $\begin{array}{c}\text { Haema- } \\
\text { tocrit } \\
(\%)\end{array}$ & $\begin{array}{c}\text { Serum } \\
\text { Iron } \\
(\mu \mathrm{g} . / \\
100 \mathrm{ml} .)\end{array}$ & $\begin{array}{c}\text { Un- } \\
\text { bound } \\
\text { Iron- } \\
\text { binding } \\
\text { Capa- } \\
\text { city } \\
\text { ( } \mu \mathrm{g} . / \\
100 \\
\text { ml.) }\end{array}$ & $\begin{array}{l}\text { Serum } \\
\text { Albu- } \\
\text { min } \\
\text { (g./100 } \\
\text { ml.) } \\
\end{array}$ & $\begin{array}{c}\text { D-xylose } \\
\text { Excretion } \\
\text { (g./5 hr. } \\
\text { urine) }\end{array}$ & $\begin{array}{c}\text { Faecal } \\
\text { Fat } \\
\text { (g./ } \\
\text { day) }\end{array}$ & $\begin{array}{l}\text { Occult } \\
\text { Blood } \\
\text { in } \\
\text { Stool }\end{array}$ & $\begin{array}{c}\text { Hook- } \\
\text { worm } \\
\text { Ova }\end{array}$ & $\begin{array}{c}\text { Intestinal } \\
\text { Biopsy }\end{array}$ \\
\hline $\begin{array}{l}1 \\
2 \\
3\end{array}$ & $\begin{array}{l}\mathrm{M} \\
\mathrm{F} \\
\mathrm{F} \\
\mathrm{M} \\
\mathrm{M} \\
\mathrm{F} \\
\mathrm{M} \\
\mathrm{M} \\
\mathrm{M} \\
\mathrm{M} \\
\mathrm{M} \\
\mathrm{F} \\
\mathrm{F} \\
\mathrm{M}\end{array}$ & 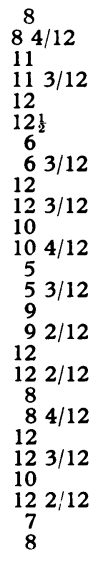 & $\begin{array}{l}a \\
b \\
a \\
b \\
a \\
b \\
a \\
b \\
a \\
b \\
a \\
b \\
a \\
b \\
a \\
b \\
a \\
b \\
a \\
b \\
a \\
b \\
a \\
b\end{array}$ & $\begin{array}{l}118 \\
119 \\
122 \\
122 \\
154 \\
154 \\
107 \\
107 \\
147 \\
147 \\
116 \\
116 \\
- \\
124 \\
124 \\
146 \\
146 \\
117 \\
117 \\
157 \\
157 \\
145 \\
145 \\
109 \\
114\end{array}$ & $\begin{array}{l}19 \cdot 7 \\
23 \cdot 1 \\
19 \cdot 0 \\
21 \cdot 8 \\
26 \cdot 3 \\
29 \cdot 0 \\
17 \cdot 2 \\
19 \cdot 5 \\
34 \cdot 0 \\
35 \cdot 8 \\
15 \cdot 4 \\
18 \cdot 1 \\
- \\
20 \cdot 0 \\
21 \cdot 8 \\
29 \cdot 5 \\
31 \cdot 8 \\
20 \cdot 9 \\
25 \cdot 9 \\
34 \cdot 5 \\
36 \cdot 3 \\
24 \cdot 5 \\
28 \cdot 6 \\
20 \cdot 0 \\
22 \cdot 2\end{array}$ & $\begin{array}{c}6 \cdot 8 \\
13 \\
2 \\
13 \cdot 2 \\
6 \cdot 0 \\
12 \cdot 6 \\
4 \cdot 0 \\
12 \\
3 \cdot 8 \\
12 \cdot 8 \\
3 \cdot 3 \\
14 \\
6 \cdot 0 \\
14 \\
1 \cdot 4 \\
12 \\
2 \cdot 4 \\
12 \cdot 2 \\
6 \cdot 0 \\
12 \cdot 5 \\
4 \\
12 \cdot 6 \\
3 \cdot 9 \\
12 \\
6 \\
7\end{array}$ & $\begin{array}{l}26 \\
41 \\
10 \\
42 \cdot 6 \\
22 \\
40 \\
16 \cdot 5 \\
37 \\
18 \\
38 \\
15 \\
45 \\
25 \\
41 \\
10 \\
38 \\
13 \\
39 \\
20 \\
40 \\
20 \\
39 \\
21 \\
38 \\
22 \\
27\end{array}$ & $\begin{array}{c}32 \\
138 \\
23 \\
100 \\
26 \\
82 \\
12 \cdot 5 \\
70 \\
33 \\
86 \\
27 \\
96 \\
37 \cdot 5 \\
76 \\
14 \\
74 \\
20 \\
86 \\
20 \\
98 \\
15 \\
81 \\
32 \\
100 \\
28 \\
31\end{array}$ & $\begin{array}{l}452 \\
288 \\
404 \\
300 \\
449 \\
344 \\
444 \\
276 \\
312 \\
296 \\
464 \\
290 \\
392 \\
260 \\
48 \\
362 \\
388 \\
298 \\
504 \\
320 \\
390 \\
280 \\
412 \\
329 \\
400 \\
386\end{array}$ & $\begin{array}{l}4 \cdot 0 \\
4 \cdot 0 \\
3 \cdot 0 \\
4 \cdot 1 \\
2 \cdot 7 \\
3 \cdot 7 \\
3 \cdot 2 \\
3 \cdot 5 \\
3 \cdot 5 \\
4 \cdot 2 \\
4 \cdot 4 \\
4 \cdot 6 \\
4 \cdot 0 \\
4 \cdot 2 \\
4 \cdot 2 \\
4 \cdot 0 \\
2 \cdot 9 \\
3 \cdot 8 \\
4 \cdot 1 \\
4 \cdot 0 \\
3 \cdot 4 \\
3 \cdot 6 \\
3 \cdot 2 \\
3 \cdot 5 \\
3 \cdot 0 \\
3 \cdot 3\end{array}$ & $\begin{array}{l}0.811 \\
1 \cdot 247 \\
1.204 \\
2 \cdot 114 \\
0.850 \\
1 \cdot 363 \\
2 \cdot 087 \\
2 \cdot 000 \\
1 \cdot 263 \\
2 \cdot 120 \\
0.877 \\
2 \cdot 010 \\
2 \cdot 046 \\
2 \cdot 110 \\
0.781 \\
1 \cdot 000 \\
0.510 \\
1 \cdot 162 \\
0.866 \\
1 \cdot 728 \\
0.517 \\
1 \cdot 891 \\
1.089 \\
1.506 \\
1.637 \\
1.069\end{array}$ & $\begin{array}{r}9 \cdot 5 \\
4 \cdot 0 \\
5 \cdot 0 \\
3 \cdot 9 \\
10 \cdot 0 \\
2 \cdot 1 \\
7 \cdot 0 \\
3 \cdot 5 \\
3 \cdot 1 \\
3 \cdot 0 \\
5 \cdot 24 \\
3 \cdot 8 \\
1 \cdot 4 \\
2 \cdot 1 \\
6 \cdot 4 \\
2 \cdot 1 \\
12 \\
3 \cdot 4 \\
6 \cdot 7 \\
2 \cdot 8 \\
8 \\
2 \cdot 6 \\
3 \cdot 7 \\
3 \cdot 0 \\
2 \cdot 8 \\
3 \cdot 1\end{array}$ & $\begin{array}{l}+ \\
+ \\
+ \\
- \\
+ \\
- \\
+ \\
- \\
+ \\
- \\
+ \\
+ \\
+ \\
+ \\
+ \\
+ \\
\overline{+} \\
\overline{+} \\
+ \\
+ \\
+ \\
+ \\
+\end{array}$ & $\begin{array}{l}+ \\
+ \\
+ \\
+ \\
+ \\
+ \\
- \\
+ \\
+ \\
+ \\
+ \\
+ \\
+ \\
+ \\
+ \\
+ \\
+ \\
+ \\
+ \\
+ \\
+ \\
+\end{array}$ & $\begin{array}{l}\text { Grade I } \\
\text { Normal } \\
\text { Normal } \\
\text { Normal } \\
\text { Grade II } \\
\text { Normal } \\
\text { Normal } \\
\text { Normal } \\
\text { Normal } \\
\text { Normal } \\
\text { Grade I } \\
\text { Normal } \\
\text { Normal } \\
\text { Normal } \\
\text { Normal } \\
\text { Normal } \\
\text { Normal } \\
\text { - } \\
\text { Grade II } \\
\text { Normal } \\
\text { Grade I } \\
\text { Normal } \\
\text { Normal } \\
\text { - } \\
\text { - }\end{array}$ \\
\hline
\end{tabular}

$a, b$, first and second investigation, which was done in Cases 1-12.

did not show any significant changes. None of the after de-worming and correction of the iron patients showed advanced villous atrophy amount- deficiency. All of them showed clinical improveing to grade III and grade IV. The investiga- ment, $\mathrm{Hb}$ rising above $12 \mathrm{~g} . / 100 \mathrm{ml}$., and serum tions were repeated in 12 children 8 to 24 weeks iron above $70 \mu \mathrm{g}$. Only 2 patients were still

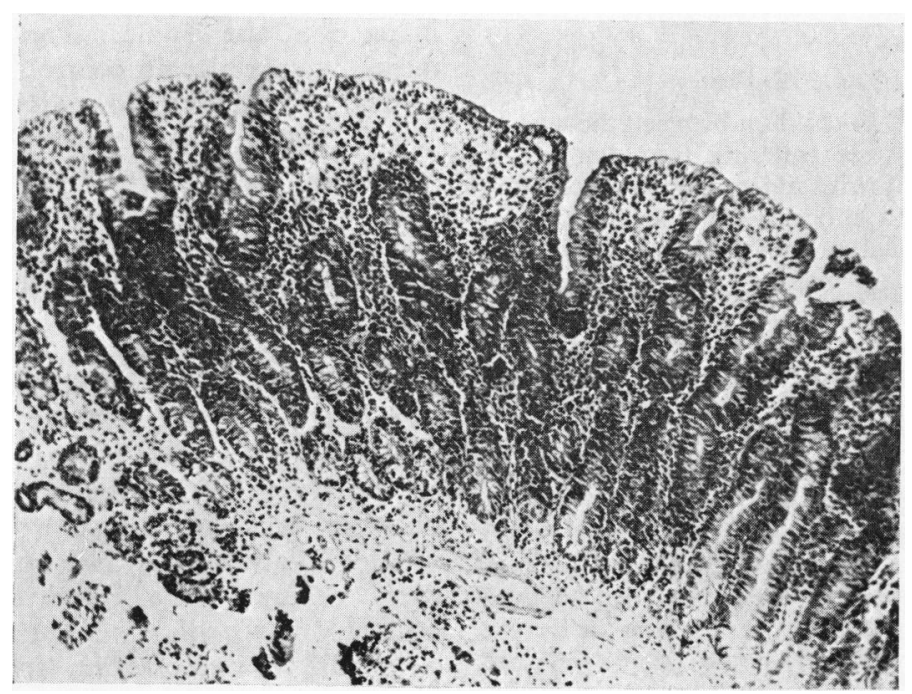

FIG. 1.-Case 3. Jejunal biopsy before therapy, showing partial villous atrophy (Grade II changes). The villi are significantly shortened, blunted, and occasionally fused. (H. and E. $\times 100$. 


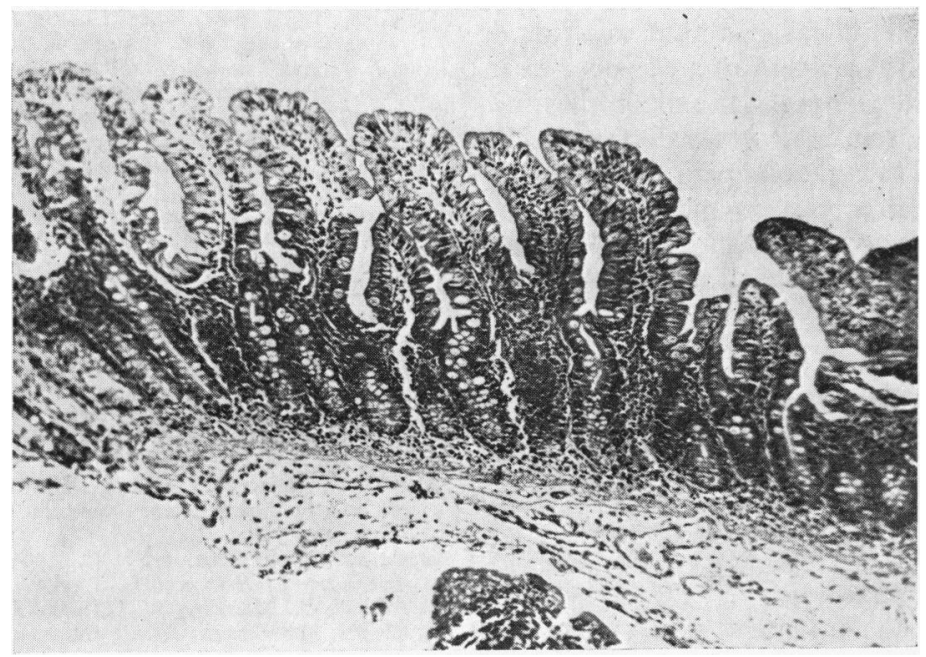

FIG. 2.-Jejunal biopsy after therapy, showing normal histological pictures. (H. and E. $\times 100$.)

harbouring hookworm. The D-xylose excretion and the fat excretion returned to normal in all the patients. Jejunal biopsy was repeated in all the 5 children who were initially abnormal, and all showed a return towards normal (Fig. 2), despite the fact that 2 of them were still harbouring hookworms. Another group of 5 children whose jejunal mucosa was normal at the time of admission showed similar findings on repeat studies.

\section{Discussion}

The results of the present study confirm the findings of Sheehy et al. (1962), Rotter (1931), Salem and Truelove (1964), Chaudhuri and Saha (1964), and Tandon et al. (1966), who have observed defective absorption of $\mathrm{D}$-xylose and/or fat in a proportion of cases of hookworm disease. It is not unreasonable to suggest that such abnormalities in the absorptive function of the small bowel have a significant effect on the clinical picture of hookworm disease. They might also explain the variable clinical picture observed in patients suffering from hookworm infection.

The incidence of significant structural changes in the present series of patients was much less than that reported in adult patients (Sheehy et al., 1962; Salem and Truelove, 1964; Chaudhuri and Saha, 1964; Tandon et al., 1966). The significance of minor abnormalities, categorized as grade $\mathrm{I}$, in tropical countries is doubtful, in view of the observation in India and South East Asia where such variations in normal have been noted before (Brit. med. J., 1965). However, grade II changes, which were observed in 2 of the 14 children, were significant enough to infer that intestinal damage of sufficient degree can take place in children with hookworm infection. Reversal of these changes after treatment is also significant in this respect.

The pathogenesis of this enteropathy in patients in the present series is speculative. Malnutrition, with its impact on small bowel function and structures, may be one factor, as it is not uncommon for these children to have low or marginal nutrition. Iron-deficiency anaemia due to hookworm infection may set up a vicious circle of intestinal damage; it is worth mentioning here that iron-deficiency anaemia can lead to epithelial abnormalities (Badenoch, Evans, and Richards, 1957; Beveridge et al., 1965; Rawson and Rosenthal, 1960; Witts, 1931), and intestinal changes have been observed in patients with iron-deficiency anaemia without hookworm infection (Naiman et al., 1964; Saha, Chatterjea, and Chaudhuri, 1965; Guha et al., 1968). Finally, parasites themselves may have a direct and damaging effect on the intestinal mucosa because of their habit of biting, or because of the production of yet undetected toxins.

The association of intestinal changes and hookworm infection makes this problem more important in tropical countries.

\section{Summary}

The structural and functional changes in the small intestine in 14 children between 4 and 12 years of age, with hookworm infection and iron-deficiency 
anaemia were studied both before and after therapy. Increased faecal fat excretion was found in 8 children, and D-xylose absorption was poor in 7 . Mild histopathological changes in the small intestine were found in 3 children, and moderate (grade II) changes in 2 . Following treatment with intramuscular iron dextran complex and bephenium, all the abnormalities reverted to normal. The possible pathogenesis and practical implications are discussed.

We are grateful to Professor V. Ramalinga Swami and Dr. M. G. Deo, Department of Pathology, All India Institution of Medical Sciences, New Delhi, for their guidance and interpretation of the histology of the jejunal biopsy specimen.

\section{REFERENCES}

Badenoch, J., Evans, J. R., and Richards, W. C. D. (1957). The stomach in hypochromic anaemia. Brit. 7. Haemat., 3, 175.

Beveridge, B. R., Bannerman, R. M., Evanson, J. M., and Witts, L. J. (1965). Hypochromic anaemia: a retrospective study and follow-up of 378 in-patients. Quart F. Med., 34, 145.

Brit. med. F. (1965). Intestinal villi. 1, 1331.

Butterworth, C. E., Jr., Perez-Santiago, E., Martinez de Jesus, J., and Santini, R. (1959). Studies on the oral and parenteral administration of $\mathrm{D}(+)$ xylose. New Engl. F. Med., 261, 157.

Chaudhuri, R. N., and Saha, T. K. (1964). Jejunal mucosa in hookworm disease. Amer. F. trop. Med. Hyg., 13, 410.

Dacie, J. V. (1956). Practical Hematology, 2nd ed. Churchill, London.

Douglas, A. S., and Dacie, J. V. (1953). The incidence and significance of iron-containing granules in human erythrocytes and their precursors. f. clin. Path., 6, 307.
Guha, D. K., Walia, B. N. S., Tandon, B. N., Deo, M. G., and Ghai, O. P. (1968). Small bowel changes in iron-deficiency anaemia of childhood. Arch. Dis. Childh., 43, 239.

King, E. J., and Wooton, I. D. P. (1956). Microanalysis in Medical Biochemistry, 3rd ed. Churchill, London.

Naiman, J. L., Oski, F. A., Diamond, L. K., Vawter, G. F., and Shwachman, H. (1964). The gastrointestinal effects of irondeficiency anemia. Pediatrics, 33, 83.

Ramsay, W. N. (1958). Plasma iron: 2. The determination of iron in serum or plasma. Advanc. clin. Chem., 1, 7.

Rawson, A., and Rosenthal, F. D. (1960). The mucosa of the stomach and small intestine in iron deficiency. Lancet, 1, 730.

Ressler, N., and Zak, B. (1958). Serum unsaturated iron-binding capacity. Amer. F. clin. Path., $30,87$.

Roe, J. H., and Rice, E. W. (1948). A photometric method for the determination of free pentoses in animal tissues. $\mathcal{F}$. biol. Chem., 173, 507.

Rotter, W. (1931). Über die histologischen Veränderungen des Dünndarms bei Ankylostomiasis. Virchows Arch. path. Anat., 280, 587.

Saha, T. K., Chatterjea, J. B., and Chaudhuri, R. N. (1965). Jejunal mucosa in iron deficiency anaemia. Bull. Calcutta Sch. trop. Med., 13, 6.

Salem, S. N., and Truelove, S. C. (1964). Hookworm disease in immigrants. Brit. med. F., 1, 1074.

Sheehy, T. W., Meroney, W. H., Coz, R. S., Jr., and Soler, J. E. (1962). Hookworm disease and malabsorption. Gastroentero$\log y, 42,148$.

Smith, C. H. (1960). Blood Diseases of Infancy and Childhood. C. V. Mosby, St. Louis.

Tandon, B. N., Das, B. C., Saraya, A. K., and Deo, M. G. (1966). Functional and structural studies of small bowel in ankylostomiasis. Brit. med. $\mathcal{F}$., 1, 714.

van de Kamer, J. H., ten Bokkel Huinink, H., and Weyers, H. A. (1949). Rapid method for the determination of fat in faeces. f. biol. Chem., 177, 347.

Williams, L. A., and Zak, B. (1957). Standardization of hemoglobin. Amer. F. clin. Path., 28, 195.

Witts, L. J. (1931). Chronic microcytic anaemia. Brit. med. F., $2,883$.

World Health Organization (1959). Iron deficiency anaemia. Report of study group. Wld Hlth Org. techn. Rep. Ser., 182. 